らな事実から，金属液体の粘性は液体の構造をよく反映す るものと考えることができよう(13).

Yao(14)によってSn，Cd，Zn 亿ついて，をた Cavalier(15) によって Feについて報告されていたような融点近傍にお ける温度履歴現象山本測定では認如らなかった。 Yao， Cavalier はとるに回転振動法によって粘度測定を行なっ たるのである。

\section{V. 結言}

金属液体の粘度を融点から広い温度範国にわたって正確 に測定することを目的として，理論的に最も確立されてい る細管法を採用し，それに対する基碟的な検討を基にして 透明石英ガラス製オストワルド型粘度計を試作した。

純金属液体の粘度の大きさ技よび温度低存性を明らかル するために， $\mathrm{Ga}, \mathrm{In}, \mathrm{Sn}, \mathrm{Bi}, \mathrm{Pb}, \mathrm{Cd}, \mathrm{Zn}, \mathrm{Sb}, \mathrm{Ag}$ および $\mathrm{Cu}$ について融点から $1100^{\circ} \mathrm{C}$ 近傍までの温度籁围にわ たって測定を行なった。湘定精度は $\pm 0.5 \%$ 程度であっ た.

測定結果炕よると，融点に括ける粘度は Andrade の式 によって整理することができた，粘度の温度依存性は近似 的に指数関数型で表わすことができたが，広い温度範围に わたっては必ずしも指数関数型で正確に記述できないこと が明らかルなった。

融点近傍における粘度の温度依存性は “正常な金属”と

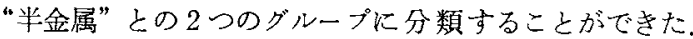

またそれはX線あるいは中性子線回折害験より得られてい る構造因子 $a(k)$ ，お上び剛体球モデルを仮定して理論的 に求められている $a(k)$ とよく対分した。

\section{文献}

（1）竹内 栄，森田善一郎，飯田孝道：金属学会誌，35 (1971), 211.

（2）竹内 栄，森田善一郎，飯田孝道：金属学会誌，35 (1971), 218.

（3）川田裕郎：中央計量検定所報告，10-2(26) (1961), 2.2 節.

（4）川田裕郎：粘度計とその取扱いの実際，オ一八社, (1962)，第 2 章.

(5) たとえば，E.N.DA C.Andrade and E.R.Dobbs : Proc.Roy.Soc.London, 211 A (1952), 12.

（6）たとえば, E.Rothwell : J.Inst.Metals, 90(1961〜 62), 389 .

(7) A.V.Grosse : J.Inorg. Nucl.Chem., 23(1961), 333

(8) J.W.Wilson: Met.Rev., 10(1965), 552.

(9) D.M.North, J.E.Enderby and P.A.Egelstaff : J.Phys.C., 1 (1968), 1075.

(10) S.P.Isherwood and B.R.Orton : Phil. Mag., 17 (1968), 561 .

（11）竹内 栄: 液体金属の構造之物性, 金属学会編, (1971), 33.

(12) N.W.Ashcroft and J.Lekner : Phys. Rev., 145 (1966), 83.

(13) E.Gebhardt und K.Köstlin: Z.Metallk., 48(1957), 601.

(14) T.Yao: Giesserei Tech.Wiss.Beiheft, 16 (1956), 837; H.R.Thresh : Trans. ASM, 55(1962), 790.

(15) B.Predel und I.Arpshofen : Z. Naturforsch., 23 a (1968) , 2052.

\title{
溶融 $\mathrm{Sb}-\mathrm{Ag}, \mathrm{Sb}-\mathrm{Au} 2$ 元系合金の活量*
}

\section{日野光久** 阿座上竹四** 龟田満雄***}

Mitsuhisa Hino, Takeshi Azakami and Mitsuo Kameda : Activity Measurements of Liquid $\mathrm{Sb}-\mathrm{Ag}$ and $\mathrm{Sb}-\mathrm{Au}$ Binary Alloys. Vapor pressure of antimony in liquid antimonysilver and antimony-gold alloys have been measured by using the transportation method between 1000 and $1200^{\circ} \mathrm{C}$ from 10 to $90 \mathrm{at} \% \mathrm{Sb}$.

The vapor pressure of each of gaseous species such as $\mathrm{Sb}, \mathrm{Sb}_{2}$ and $\mathrm{Sb}_{4}$ was calculated for pure antimony and several liquid alloys from the data obtained in the present work and the available data on the equilibrium among these gaseous species.

Activities of antimony were determined from the vapor pressures of antimony, while those of silver and gold were derived by the Gibbs-Duhem integration. Activities of each component exhibit considerable negative deviations from Raoult's law except activities of antimony which show positive deviations in the $\mathrm{Sb}-\mathrm{rich}$ region. Activity curves of antimony at various temperatures show a crossover point at about $75 \mathrm{at} \% \mathrm{Ag}$ and $53 \mathrm{at} \% \mathrm{Au}$ in the respective systems,

** 東北大学工学部金属工学科(Department of Metallurgy, Faculty of Engineering, Tohoku University, Sendai)

*** 東北大学工学部, 現在 : 秋田工業高等専門学校(Faculty of Engineering, Tohoku University, Sendai. Present address : Akita Technical College, Akita)

* 溶融アンチモン系合金化関する熱力学的研究 (第 1 報) 
and they approach Raoult's law with increasing temperature in the $\mathrm{Ag}$ or $\mathrm{Au}$ richer side from these compositions. At these points, the partial heat of mixing of antimony, $\Delta \bar{H}_{\mathrm{Sb}}$, shows anomalous behavior that changes from negative to positive with increasing antimony content in alloys.

(Received May 2, 1975)

\section{I. 緒言}

アンチモンはヒ素とともに非鉄金属製錬におけるスパイ スの基本成分であり，乾式製鍊の段階でしばしば問題を起 こす。このような不純物としてのアンチモンを除去する上 でも，またアンチモンを副産的に回収する上においてもフ ソチモン系各種溶融合金系の化学熱力学的珄質を知ること は非常に重要である。ささらアンチモンは周期表において $\mathrm{V}_{\mathrm{b}}$ 族に属することから，半金属，半導体的な性質を有す ること，また蒸気相に拈いて $\mathrm{Sb}, \mathrm{Sb}_{2}, \mathrm{Sb}_{4}$ の各種蒸気種を 形成することからアンチモン系合金融体に执いても特異な 挙動を示すことが考克られ，溶液論的見地からも大いに與 味が持たれるが，從来報告されている高温に批ける溶融つ ソチモン系合金関する熱力学的データは比較的少ない， このような見地に立ち各種溶融フンチモン 2 元系合金の活 量測定を叔こならことを計画した。

本報告で取り上げた $\mathrm{Sb}-\mathrm{Ag}$ 采については Nozaki ら(1), Okajima ら ${ }^{(2)}$ 化よる起電力法による活量測定，执よび植 村 ${ }^{(3)}$ による混合熱の测定があるのみである。しかし Okajima らは固体状態の銀を基準として測定を行なって いる，一方 $\mathrm{Sb}-\mathrm{Au}$ 系については著者ら ${ }^{(4)}$ が本実験と平行 して行なった起電力法による活量測定があるのみである が，その測定温度範囲は本研究よりもかなり低い。

そこで本研究では $\mathrm{Sb}-\mathrm{Ag}, \mathrm{Sb}-\mathrm{Au}$ 各 2 元系合金につい て，より高温でのデータを得ることを目的とし，流動法を 用いて全組成範囲について，1000 $1200^{\circ} \mathrm{C}$ の温度籁柬に わたりアンチモンの蒸気压を測定し，活量を初めとする熱 力学的諸量を導いた。

\section{II. 実 験 原 理}

金属試料を反応管内で一定温度に保持すれば一定の蒸気 正を呈し，金属とそのガスとの間に平衡が成立する。この 試料上に流動ガス(carrier gas)をゆっくり流し, 生成し た金属の蒸気で館和させ，平衡を崩さずにガスを系外に取 り出しがス中に含まれる試料蒸気を定量し, 試料の示す蒸 気圧を測定する方法が本研究で採用した流動法(5)である。

実際の方法としては反充管中の合金試料の回りに通常不 活性の流動ガスを流し，試料蒸気で飽和したガスをコンデ ンサに導く，流動ガス中に含をれる陚料蒸気を全てコンデ ンサに凝縮させ，その凝縮量を定量することによって式 （1）を用いて合金試料中の揮発成分 Sの蒸気压 $p_{\mathrm{S}}$ を決定 することができる.

$$
p_{\mathrm{S}}=\frac{n_{\mathrm{S}}}{n_{\mathrm{S}}+n_{\mathrm{G}}} P
$$

ただし $n_{\mathrm{S}}$ ：流動ガスによって運ばれた合金中の成分 Sの モル数， $n_{\mathrm{G}}$ : 使用した流動ガスのモル数， $P$ : 反応管内の 全圧である。しかし本実験の対象であるアンチモンはガス 相汇执いて $\mathrm{Sb}, \mathrm{Sb}_{2}, \mathrm{Sb}_{4}$ と 3 種類のガス種 ${ }^{(6)}$ が報告されて 扣り，式(1)によって単純にアンチモンの蒸気圧を決定す ることはできない，そこで，アンチモン系合金試料と平衡 しているガス相中の 3 種類のアンチモンガス種を，全て単 原子分子(Sb)だけで構成されていると仮定し，式(1)を用 いて求めたアンチモンの蒸気圧を見掛けの蒸気压として $p_{\mathrm{m}}$ とすると，式(1)性分纴則から式(2)の上うに書くこ とができる。

$$
p_{\mathrm{m}}=\frac{p_{\mathrm{Sb}}+2 p_{\mathrm{Sb} 2}+4 p_{\mathrm{Sb}_{4}}}{p_{\mathrm{Sb}}+2 p_{\mathrm{Sb}_{2}}+4 p_{\mathrm{Sb}_{4}}+p_{\mathrm{G}}} P
$$

ただし $p_{\mathrm{Sb}}, p_{\mathrm{Sb}_{2}}, p_{\mathrm{Sb}_{4}}$ ：そ礼ぞれアンチモンの単原子分子， 2 原子分子， 4 原子分子の示寸蒸気压， $p_{G}$ : 流動ガスの分

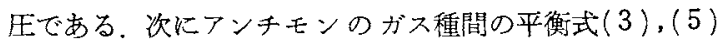
の各平衡定数を $K_{1}, K_{2}$ とする。 また反応管内に打いては 式(7)が成立する。

$$
\begin{aligned}
2 \mathrm{Sb} & =\mathrm{Sb}_{2} \\
K_{1} & =p_{\mathrm{Sb}_{2}} / p_{\mathrm{Sb}}^{2} \\
4 \mathrm{Sb} & =\mathrm{Sb}_{4} \\
K_{2} & =p_{\mathrm{Sb}_{4}} / p_{\mathrm{Sb}}^{4} \\
p_{\mathrm{Sb}}+p_{\mathrm{Sb}_{2}} & +p_{\mathrm{Sb}_{4}}+p_{\mathrm{G}}=P
\end{aligned}
$$

式(4)，(6)，(7)を式(2)に代入し，フンチモンの単原 子分子の蒸気压 $p_{\mathrm{Sb}}$ について整理すると式(8)が得られ る.

$$
K_{2}\left(4 P-3 p_{\mathrm{m}}\right) p_{\mathrm{Sb}}^{4}+K_{1}\left(2 P-p_{\mathrm{m}}\right) p_{\mathrm{Sb}}^{2}+P p_{\mathrm{Sb}}-p_{\mathrm{m}} P=0(8)
$$
$K_{1}, K_{2}$ が既知の值であれば，湘定より得た $P$ 括よび $p_{\mathrm{m}}$ を 式(8)に代入し解沽ばアンチモンの単源子分子の蒸気圧 $p_{\mathrm{Sb}}$ を得ることができ，さらに式(4)，(6)より $p_{\mathrm{Sb}_{2}}, p_{\mathrm{Sb}_{4}}$ の値も計算できる. 本実験では $K_{1}, K_{2}$ の值は Hultgren $ら^{(6)}$ の $p_{\mathrm{Sb}}, p_{\mathrm{Sb}_{2}}$, $p_{\mathrm{Sb} 4}$ の推奖值を用いて求めた。 また反応 管内の全圧は，本装置では大気圧とほとんど等しいため， 测定するたびに大気圧を測定して用いた。

\section{III. 実 験方 法}

本実験で用いたアンチモンは $99.999 \%$ 以上，銀，金は 99.99\%以上の純度である。合金試料の作製においては， 各成分の蒸気印がいずれも低い值を示すことから特別の装 置は用いなかった。すなわち $\mathrm{Sb}$ と $\mathrm{Ag}$ または $\mathrm{Sb}$ と $\mathrm{Au}$ を目的組成清科しアルミナボートに入れ，その組成の液 相線温度より $50 \sim 100^{\circ} \mathrm{C}$ 高い温度で $30 \mathrm{~min}$ 保持して合金 組成を均一化してから測定を行なった。

测定中，試料から合金成分が揮発するので試料の組成が 
変化する，そこで各測定ごとに試料全体の重量減少を測定 して扣き，実験終了後合金試料の分析を行ない，湘定前の 試料の組成および測定による試料の重量変化から各測定の 組成を追跡決定した。

本実験で用いた流動法の反応管部を Fig.1 亿示す，石 英製の反応管は中央部にキャピラリのある隔壁を有し，試 料蒸気で飽和した流動ガスはこのキ+ピラりを通って石英 製のコンデンサに尊かれる。 また試料のまわりの空間をで きる限り小さくし，流動がスと試料の接触を十分に行ない 速やか纪飽和状態にするとともに，温度勾配に上る試料蒸 気の熱搪散を防止するためにスペーサを使用した，流動が スは前述したごとく試料蒸気によって完全に飽和していな ければならないが，本赛験装置では予備実唭により 60〜 $120 \mathrm{cc} / \mathrm{min}$ の流速で蒸気圧が一定となることを予め確か め,この範围内で測定をおこなった。流動ガスとしては $\mathrm{CO}$ ガスを $0.5 \%$ 混合した $\mathrm{N}_{2}$ ガス立たは $\mathrm{Ar}$ ガスを精製 して用いた，温度は補正した $\mathrm{Pt}-13 \% \mathrm{Rh} / \mathrm{Pt}$ 熱電対を用 いて測定し，測定中の温度変化は $\pm 0.5^{\circ} \mathrm{C}$ 以下に保った。

測定はFig.1の上うに試料ボート，スペーサ，コンデン サをセットし反仙管内を流動ガスで十分に真空置換した 後，予熱して狲いた電気炻を試料の位置に動かし試料を測 定温度まで速やかに昇温させる。ただし温度が変化してい る間に試料から揮発する蒸気がコンデンサに入らないよう にするため，少量のガスを測定時とは逆の力向，すなわち 図の右から左へ流しておく。試料が測定温度に安定した後 ガスを図中左から右へ流し，測定を開始し、コンデンサに 導いた試料蒸気を凝縮させる。一力おキピラリを通った流 動ガスが速やかに，かつ総てコンデンサに入るように反応 管の右側からコンデンサの外側に少量の補助がスを流し， 㼨壁の右側でコンデンサの内側に流れ込むようにする。 たコンデンサは流動ガスによって運ばれた試料蒸気を完全 に捕捉するために，反忘管の外側から冷却すると同時にコ ンデンサ内にグラスウールをゆるく詰めてある。所定の測 定時問の後，流動ガスを測定開始前々同じ这方向に切替 え，電気忓を移動し試料を冷却する。このように試料が一

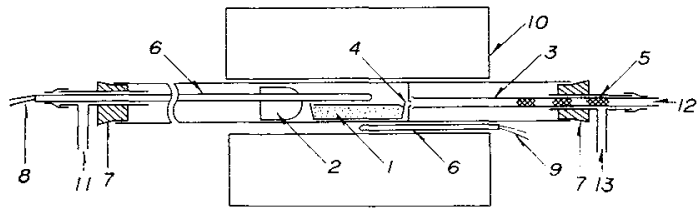

1. Sample in alumina 8. Thermocouple for boat

2. Spacer

3. Condenser

4. Capillary

5. Glass wool measurement

9. Thermocouple for control

10. Kanthal wound furnace

6. Alumina sheath

7. Silicone rubber stopper

Fig.1 Transportation apparatus.
定温度に安定しているときだけの掸発量を測定し，正確な 蒸気任を得るように工夫した。

本実験においては，合金試料から揮発するのはフンチモ ンだけでなく銀あるいは鉝の揮発も考えられる。そこで 銀，金の多い合金試料の測定で得られたコンデンサの凝縮 物を酸で溶解し原子吸光法で分析をおこなったところ， 90 at\% Au 合金試料についての凝縮物中には金はトレー スにすぎず，凝縮物の重量への金の影響は無視できること が確かめられた。一方 $\mathrm{Sb}-\mathrm{Ag}$ 系についてて 60 at\% $\mathrm{Ag}$ 以 下の組成の合金についての凝縮物中心は鋜の存在注ほとん ど喼められなかったが，70 at％ Ag 以上銀を含有する試料 の測定で得られた凝縮物中には銀が認められたので，原子 四光法により分析を扣こない合金試料からの揮発量を決定 した. Sb-Ag 系では 60 at \% Ag 以下，Sb-Au 系では測定 した全組成範囲での，凝縮物中に $\mathrm{Ag}$ 交たは $\mathrm{Au}$ の認めら れないいくつかのコンデンサ炕いて，分析によって求め たアンチモンの揮発量とコンデンサの凝縮物による重量增 加との間には $0.5 \%$ の䛊差範囲内で一致することが認めら れた，そこでこれらの組成での測定の大部分ではコンデン サへのアンチモンの凝縮量心ュンデンサの重量変化を溳定 することによって決定した。

\section{IV. 測定結果および考察}

装置ならびに測定方法の妥当性を確かめることを目的と し，予借実験として純鉛㧍よび綂アンチモンの蒸気圧を測 定したところ, 報告されている值と良く一致する結果が得 られた，Fig.2に本装置を用いて測定した純アンチモンの 蒸気圧について式(8)を用いて求めた $p_{\mathrm{Sb}}$, さらに $p_{\mathrm{Sb}} よ$ り式(4)，(6)によって計算した $p_{\mathrm{Sb}_{2}}, p_{\mathrm{Sb} 4}$ および $p_{\mathrm{Sb} \text { (total) }}$ $\left(p_{\mathrm{Sb}}+p_{\mathrm{Sb}_{2}}+p_{\mathrm{Sb}_{4}}\right)$ を示したが，実線で示した Hultgren ら ${ }^{(6)}$

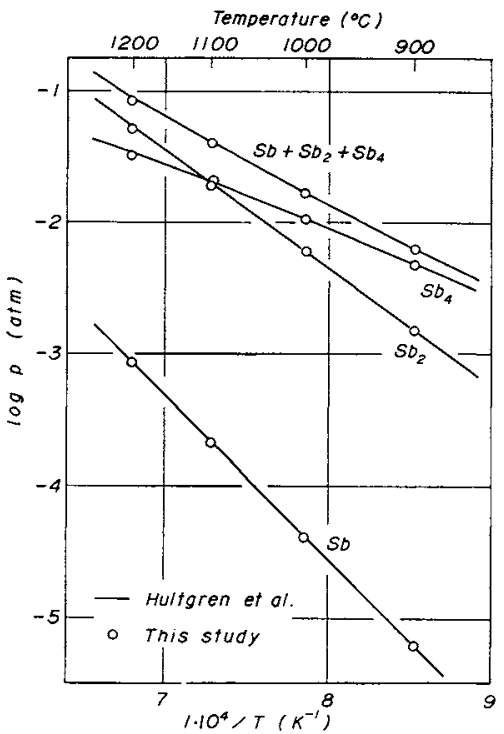

Fig.2 Vapor pressure of pure antimony measured. 
の推奖値と非常に良く一致している. 本矿究ではこの測定 で求めたアンチモンの蒸気压を $p_{\text {Ś }}^{\circ}$ として用い，次式によ り活量を算出した。

$$
a_{\mathrm{Sb}}=p_{\mathrm{Sb}} / p_{\mathrm{Sb}}^{\circ}
$$

\section{1. $\mathbf{S b}-\mathbf{A g}$ 系}

$\mathrm{Sb}-\mathrm{Ag}$ 系机いて $1000,1100,1200^{\circ} \mathrm{C}$ の各温度で求め た活量をFig.3 亿示寸。本実験では Ar ガスと，0.5\% CO-

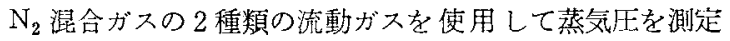
したが，測定絬果俧差認められなかった。アンチモンの 活量曲線は図より明らかなごとく大部分の組成範囲では Raoult 則より負に偏倚しているが,Sb 側ではわずかながら 正炕偏倚する.Fig.4 に示した Sb-Ag 系状態図 (7)によれば $\mathrm{Ag}$ 側に多くの固溶体が存在しておりここれが融体におい

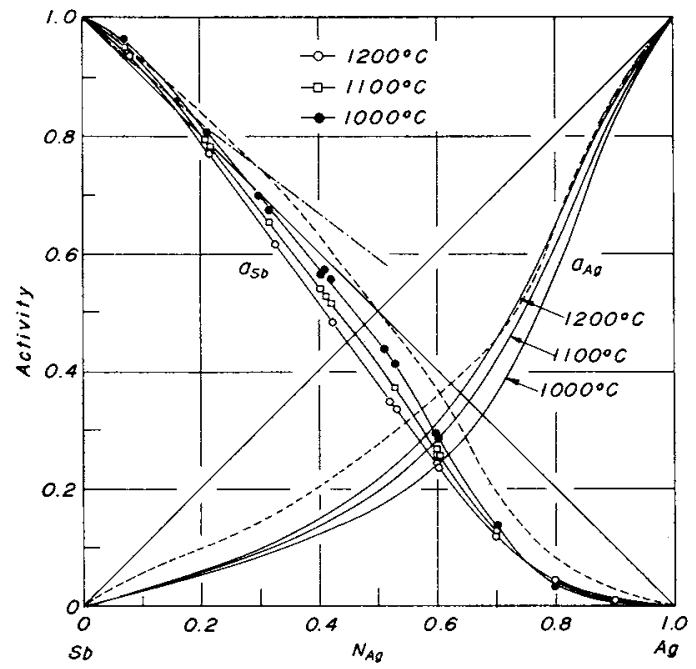

Fig.3 Activities of antimony and silver in liquid $\mathrm{Sb}-\mathrm{Ag}$ alloys.

--.-- Nozaki et al. (1300K)

-. - calculated from phase diagram $\left(1000^{\circ} \mathrm{C}\right)$

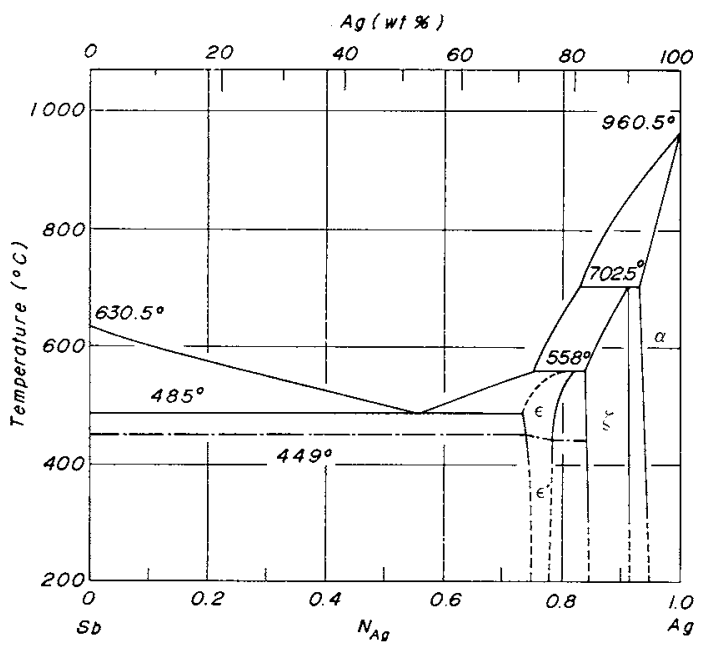

Fig.4 Phase diagram of $\mathrm{Sb}-\mathrm{Ag}$ system ${ }^{(7)}$.
ても影響を及ぼしていると考えられる。また $N_{\mathrm{Ag}}=0.8$ お よび 0.9 ，すなわちアンチモンの割合が少ない組成でのア ンチモンの活量は温度の上昇とともにその変化量は小さい が Raoult 則に近づくといら一般則に従うが, $N_{\mathrm{Ag}}=0.7$ 以 下の広い組成範囲では反対に温度の上昇とともに Raoult 則からの偏倚を大きくし， $N_{\mathrm{Ag}}=0.75$ 付近で各温度の活量 曲線が交差し温度依存性を失なら点が存在する。この交差 する現象は Nozaki ら(1)の報告でも $\Delta \bar{H}_{\mathrm{Sb}}$ に見られるよう に明らかであり，その組成も良い一致を得ている。この組 成は状態図における $\epsilon$ 固溶体に近い，本測定での $a_{\mathrm{Sb}}$ は Nozaki らの測定結喿よりも全組成範团で低い値を取って いるが，活量曲線が Raoult 則と交差していることをも含 め，その挙動は非常に類似した傾向を示している。

これらの $a_{\mathrm{Sb}} よ り$ Gibbs-Duhem 式を $\alpha$ 関数を用いて 図上積分を和こない求めた銀の活量檤は全組成範囲で Raoult 則から負に偏倚している，また温度の上昇ととも にとの值は Raoult 則に近づくという溶液の一般則を满足 している.これらの値は Nozaki らの睍定結果と比較した 場合， $N_{\mathrm{Ag}}=0.7$ 以下ではかなり低い值を示しているが， それ以上の組成範围ではかなり近い值を示している。 正則溶液を仮定し，状態図の液相線から $1000^{\circ} \mathrm{C}$ に括ける $a_{\mathrm{Ag}}$ 計算 ${ }^{(8)}$ したところ Fig.3に示すごとくあまり良い一 致は見られなかった。

本実験の $1000 \sim 1200^{\circ} \mathrm{C}$ の温度籁田で混合熱老計算し図 示したのが Fig.5 である.アンチモンの部分混合熱 $\Delta \bar{H}_{\mathrm{Sb}}$ は銀の割合の增加とともに $N_{\mathrm{Ag}}=0.75$ 付近で正から負へ と变化する。この組成は活量の温度依存性が逆になる組 成，すなわちFig.3に推㚈る活量曲線が交差する点に当 る.これはFig.5 飞点線で示した Nozaki ら ${ }^{(1)} の$ 测定結果 でも全く同じ組成で生じていることが諗められる。高た䅡 分量である混合熱 $\Delta H_{M}$ は $\mathrm{Sb}$ 側でわずかに正の值を示す が，固溶体の多く存在する $\mathrm{Ag}$ 側では負の値を示す．混合 熱につては植村 ${ }^{(3)}$ による直接測定があり，Fig.5K示し たごとくAg 側に打いては大きな差を生じるが,Nozaki ら

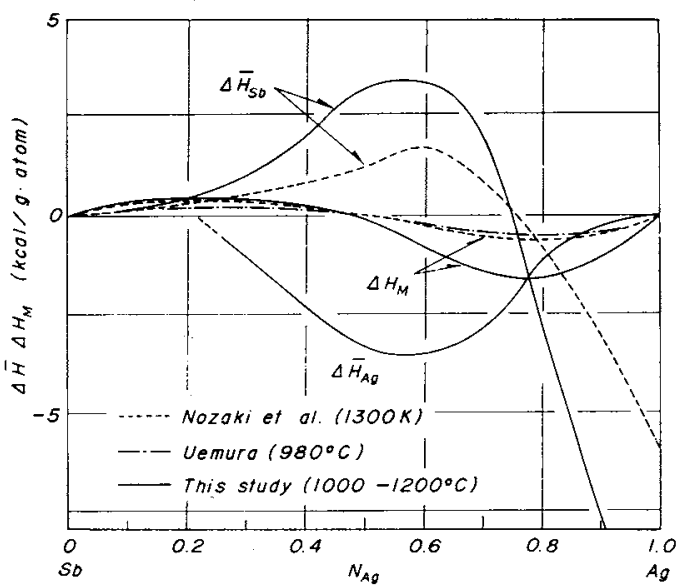

Fig.5 Heat of mixing in liquid $\mathrm{Sb}-\mathrm{Ag}$ alloys. 
の測定とも去の挙動は良く似ており，特に吸熱反応を示す $\mathrm{Sb}$ 側ではその值も割合良く一致する。また他の測定者之 同様 $N_{\mathbf{A g}}=0.8$ 付近で負の最大值を示すが，この組成は $\epsilon$ 固溶体の組成近い。

蒸気压の測定により間接的に混合熱を計算する場合，を の部分混合熱は活量と温度の関係から算出するが，本系の 上らに活量值が非常に小さい場合，活量値がわずかに変化 してもその対数は大きな変化となり大きな䛊差となって現 われる。これが Ag 侧での大きな差となったものと考兄ら れる。

理想溶液からの偏倚を知る量として，Fig.5 亿示した $\Delta H_{\mathrm{M}}$ の他に過剩混合自由エネルギ $\Delta G_{\mathrm{M}}^{\mathrm{EX}}$ がある。これを

Fig.6に示した。これは活量図からも明らかなようにかな り大きな貨への偏倚があり，そのピークは $N_{\mathrm{Ag}}=0.7$ 付近 に存在する。この組成はフンチモンの活量曲線が交差する $\epsilon$ 固溶体組成と大略一致して招り與味深い。

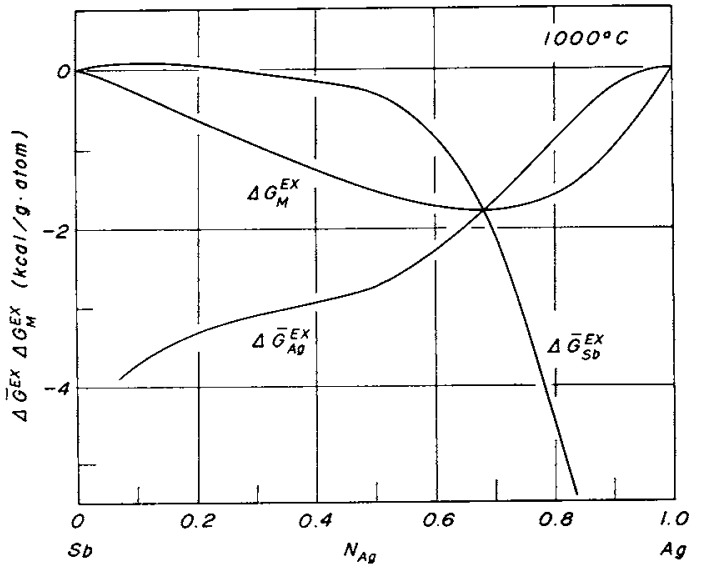

Fig.6 Excess free energy of mixing in liquid $\mathrm{Sb}-\mathrm{Ag}$ alloys at $1000^{\circ} \mathrm{C}$.

\section{2. $\mathbf{S b - A u ~}$ 采}

測定により得た溶融 Sb-Au 合金中のアンチモンの活 量，および Gibbs-Duhem 式の積分によって計算した金の 活量をFig.7亿示した。アンチモンの活量は大部分の組 成でRaoult 則から大きく負に偏渏しているが,銀の場合と 同様 $\mathrm{Sb}$ 側でわずかながら正に偏倚する。このような負の 偏倚はFig.8亿示した状態図(7)にあるごとく, AuSb $_{2}$ なる 金属間化合物の影響と考えられる，また湜度による活量值 の変化を Sb-Ag 系汇比較すると，その温度依存性は非常 に小さい，特住 $N_{\mathrm{Ag}}=0.5$ 抢よび 0.6 ，特に前者の組成で の測定点徃重なり合い同一値としか見ることはできない， しかし $N_{\mathrm{Au}}=0.7$ の活量值は明らか炕 $1000^{\circ} \mathrm{C}$ よりも 1200 ${ }^{\circ} \mathrm{C}$ での浿定が大きな值を有する，また $N_{\mathrm{Au}}=0.9$ では， $1100^{\circ} \mathrm{C}$ 以下でアンチモンの蒸気生山本装置で正確な測走 が可能な值よりも低い蒸気圧を示し，測定は不可能であっ た. 以上のことから $N_{\mathrm{Au}}=0.4$ から 0.7 の間で活量曲線が 交差しているとこは明らかであり，大略 $N_{\mathrm{Au}}=0.53$ がそ

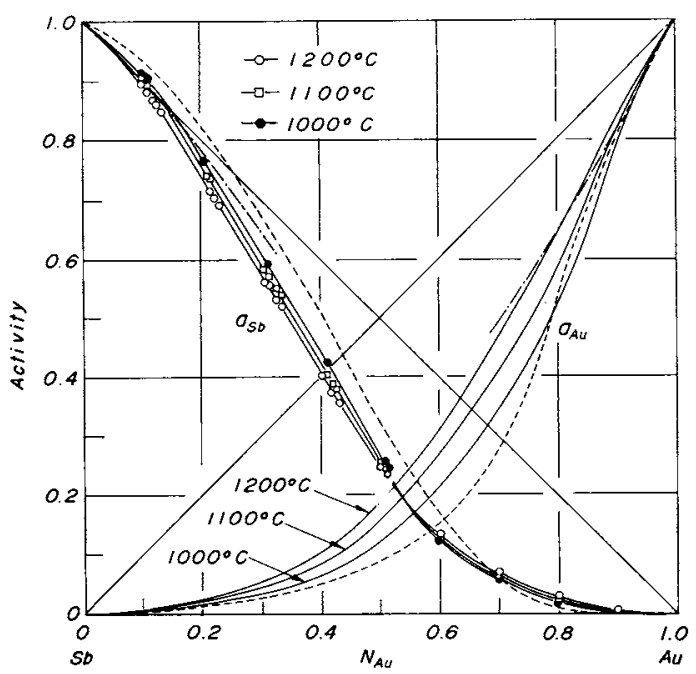

Fig.7 Activities of antimony and gold in liquid $\mathrm{Sb}-\mathrm{Au}$ alloys.

--.--- Kameda et al. $\left(800^{\circ} \mathrm{C}\right)$

- - calculated from phase diagram $\left(1000^{\circ} \mathrm{C}\right)$

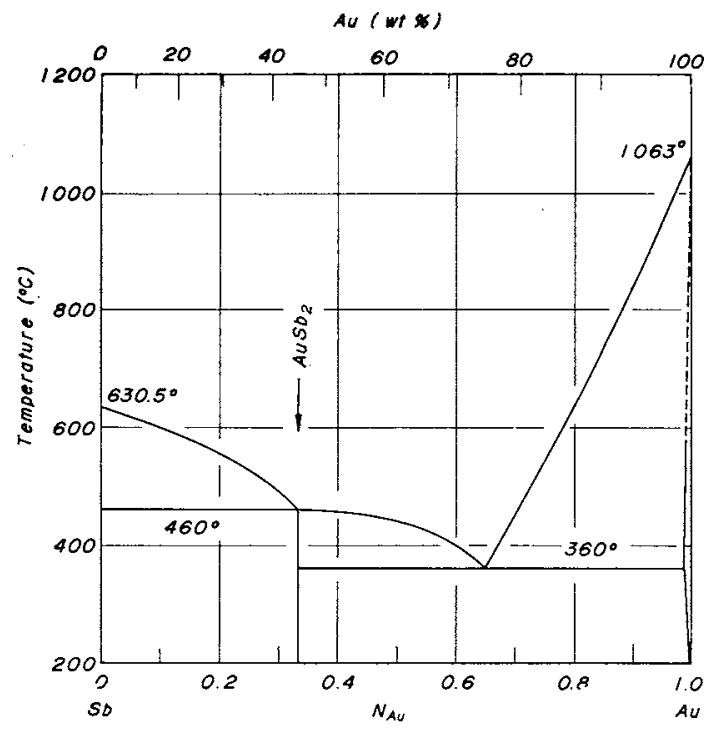

Fig.8 Phase diagram of Sb-Au system(7).

の組成であると推定した。このよらに $\mathrm{Sb}-\mathrm{Au}$ 系において も前述の $\mathrm{Sb}-\mathrm{Ag}$ 系とはその組成は異なるが，活量の㻗度 依存性が逆転している。この現象㒂者らが起電力法で测 定したAu-Sb 系(4)においても，また本案験と同じ流動法 で湘定した $\mathrm{Cu}-\mathrm{Sb}$ 系 ${ }^{(9)}$ 儿も同稼に見られる，Fig.7に点 線で示したのは急田ら ${ }^{(4)}$ が起電才法により測定した $800^{\circ} \mathrm{C}$ での健であり，温度差を考慮すれば本実験の結果とよく一 致しているといえるであるう。

一方金の活量は全組成で Raoult 則より負の偏倚を示し て扣り，その值は銀の場合と同様，温度の上昇により Raoult 則に近づくといら溶液の活量の温度変化の一般 
的な挙動に従っている。このように両合金系の成分の 活量の挙動は極めて類似した傾向がみられる。しかし Kubaschewski の方法 ${ }^{(8)}$ により状態図より計算した 1000 ${ }^{\circ} \mathrm{C}$ の活量值は測定值とはかなり異なった㖽向が見られる。

溶液中の成分の活量は，温度の上昇とともに配列の不規 則性を增すために Raoult 則に近づくのが普通である。し かし Sb-Cu 系をも含めて本研究の範囲内では，アンチモ ンの活量值の温度体存性はSb-Au 系では不明瞭であるが， $\mathrm{Sb}-\mathrm{Ag}$ 系では $\epsilon$ 固溶体, $\mathrm{Sb}-\mathrm{Cu}$ 系では $\beta$ 固溶体之，ほぼ 金属間化合物や 2 次固溶体胝近組成で逆転しここれり アソチモンの希薄な組成範囲では温度の上昇とともに Raoult 則に近づくが，Sbに近い側では反対に Raoult 則 から離れるという傾向が見られる，その理由につてて考 察にはさらに多くのアンチモン系合金についての詳細な測 定がなされる必要があるが，このような傾向はSbのよう な $\mathrm{V}_{\mathrm{b}} ， \mathrm{I}_{\mathrm{b}}$ 族元素を含む溶融合金系にしばしば見られる 挙動であり極めて興味深い.

$1000 \sim 1200^{\circ} \mathrm{C}$ の温度範囲で計算した混合熱を Fig.9に 示す. Sb-Au 系については混合熱の直接測定が見当らな いためこれらの值との比較はできないが，図中に点線で示 した起電力法による值とよく一致している。この系に㨟い てもアンチモンの部分淈合熱 $\Delta \bar{H}_{\mathrm{Sb}}$ は $\mathrm{Sb}-\mathrm{Ag}$ 系之同様の 挙動を示し， $\Delta \bar{H}_{\mathbf{S b}}$ はアンチモンの割合が減少すると正か ら負へ变化する組成にやや差梳あるが，起電力法に上る結 果と極めて類似した傾向が見られる．Sb-Cu，Sb-Ag，Sb$\mathrm{Au}$ 系虫ずれも $\mathrm{Sb}-\mathrm{I}_{\mathrm{b}}$ 族合金系であり，状態図的には 前 2 者がやや類似しているが Sb-Au系は異なっており， この上らな $\Delta \bar{H}_{\mathrm{Sb}}$ の挙動はアンチモン系融体に共通のもの と考えられ與味が持たれる。Fig.10に $1000^{\circ} \mathrm{C}$ にお㹁る 過剩混合自由エネルギを示寸が $\mathrm{Sb}-\mathrm{Ag}$ 系よりもかなり大 きな負の扁倚を示して拉り，理想状態からの偏倚の大きい ことを示している.

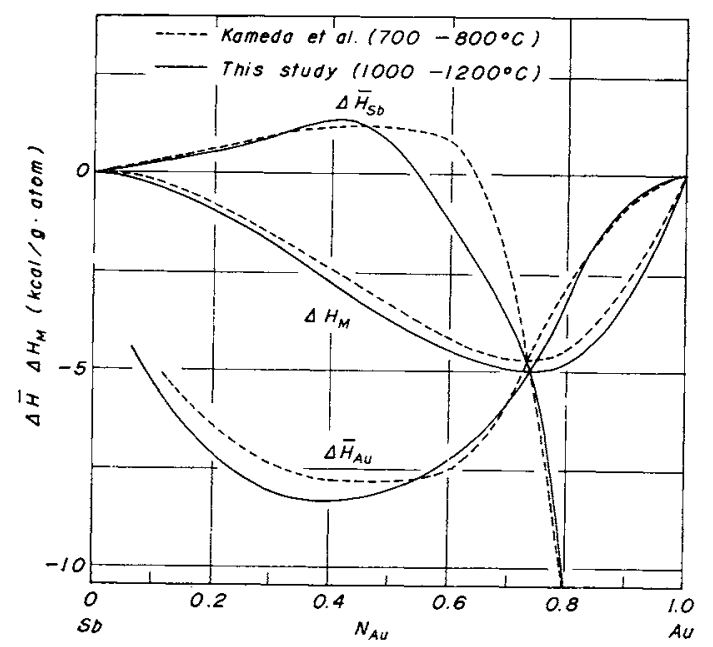

Fig.9 Heat of mixing in liquid $\mathrm{Sb}-\mathrm{Au}$ alloys.

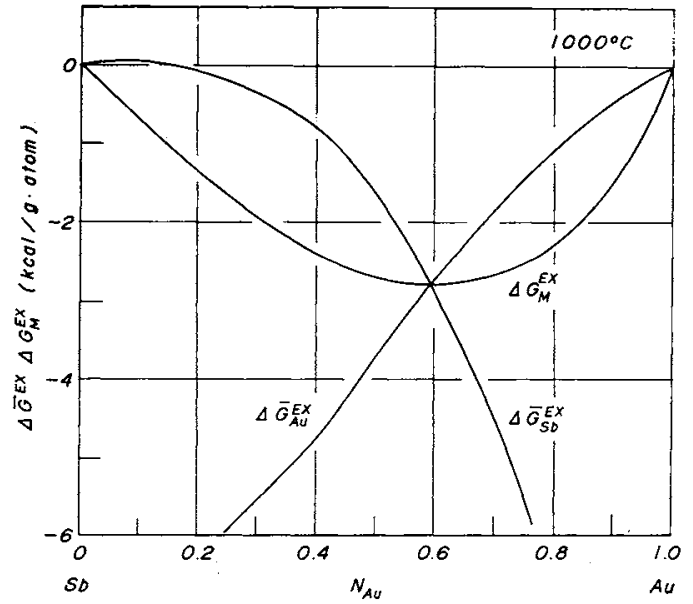

Fig.10 Excess free ernergy of mixing in liquid $\mathrm{Sb}-\mathrm{Au}$ alloys at $1000^{\circ} \mathrm{C}$.

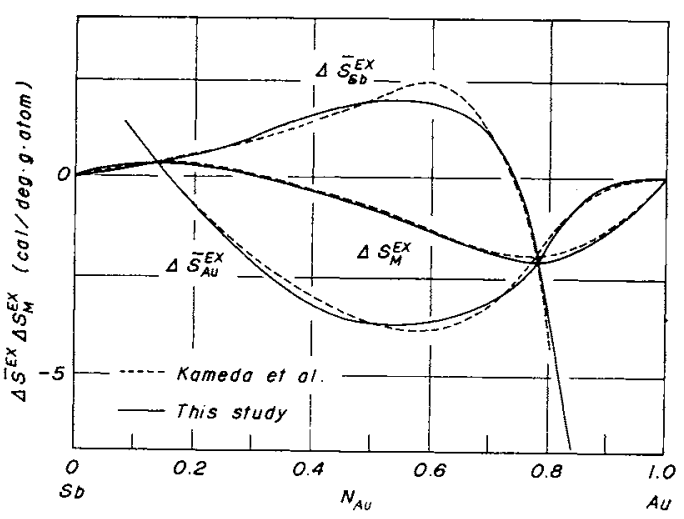

Fig.11 Excess entropy of mixing in liquid $\mathrm{Sb}-\mathrm{Au}$ alloys.

$1000^{\circ} \mathrm{C}$ に和ける過剩混合エントロピをFig.11に示す。 起電力法 (4)により $800^{\circ} \mathrm{C}$ で求めた置と本実験で求めた值 は極めて良い一致を示した。

\section{3. 銀または金中のアンチモンの除去}

本実験の結果に基づき，銀まなは鍂中のアンチモンを乾 式法によって除去する場合について考劣てみる。

测定によって得られたアンチモンの活量係数て $N_{\mathrm{Sb}}=0$ 屯で外挿し，アンチモンの然限希薄溶液の活量係

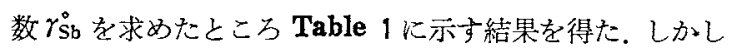
実験方法で記述したごとく，Sb-Ag 系合金においては鋜側 の組成でアンチモンとともにかなりの量の銀が揮発する.

Table 1 Activity coefficients of antimony in infinite dilute solution, $\gamma_{\text {Sb }}^{\circ}$.

\begin{tabular}{c|c|c|c}
\hline & \multicolumn{3}{|c}{$\gamma_{\text {Sb }}^{\circ}$} \\
\hline Temp. $\left({ }^{\circ} \mathrm{C}\right)$ & 1000 & 1100 & 1200 \\
\hline $\mathrm{Sb}-\mathrm{Ag}$ & 0.0077 & 0.0213 & 0.0296 \\
$\mathrm{Sb}-\mathrm{Au}$ & 0.0011 & 0.0073 & 0.0164 \\
\hline
\end{tabular}


そこで蒸気压と得られた活量值からアンチモンの全圧 $p_{\text {Sb(total) }}$ 䤽の蒸気压を比較したところ, $1000^{\circ} \mathrm{C}$ において $N_{\mathrm{Ag}}=0.82,1200^{\circ} \mathrm{C}$ で 0.79 で両者が等しくなる.この組 成を銀中からのアンチモンの揮発に上る除去限界と考允れ ば，それぞれ 20，23 wt\% Sb に相当し，純粋状熊で 1000 ${ }^{\circ} \mathrm{C}$ で銀より 3 オーダも高い蒸気压を示すアンチモンも銀 中から揮発除去することは困難であることが判る。

しかし銀は 1 気王の純酸素中でも酸化しないことから， 銀中のアンチモンを空気中で酸化除去することを考方る 之，その反応式恃式(10)，反応の自由エネルギ変化住式 (11)のように与えられる(10)。銀の酸化の式(12)，(13)よ

$$
\begin{gathered}
3 \mathrm{Ag}_{2} \mathrm{O}(\mathrm{s})+2 \mathrm{Sb}(\mathrm{l})=6 \mathrm{Ag}(\mathrm{s})+\mathrm{Sb}_{2} \mathrm{O}_{3}(1) \\
\Delta G_{\mathrm{T}}^{\circ}=-137040+8.58 \mathrm{~T} \\
4 \mathrm{Ag}(\mathrm{s})+\mathrm{O}_{2}(\mathrm{~g})=2 \mathrm{Ag}_{2} \mathrm{O}(\mathrm{s}) \\
\Delta G_{\mathrm{T}}^{\circ}=-13440+28.98 \mathrm{~T}
\end{gathered}
$$

$\eta^{(10)}, p_{\mathrm{O}_{2}}=0.21$ を与克机ば $a_{\mathrm{Ag}_{2} \mathrm{O}}=0.0044$ となり，かな り小さな值となる。共补ええ $\mathrm{Sb}-\mathrm{Ag}$ 系合金から $\mathrm{Sb}_{2} \mathrm{O}_{3}$ が

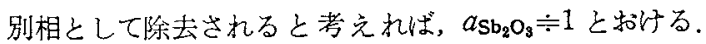
ここで $a_{\mathrm{Ag}}=1$ とすれば $1000^{\circ} \mathrm{C}$ におけるアンチモンの酸 化除去の限界は $a_{\mathrm{Sb}}=5.02 \times 10^{-8}$ ，これを福を用いて换算 すると $7.36 \times 10^{-4} \mathrm{wt} \% \mathrm{Sb}$ となる。

さらに溶融 $\mathrm{Sb}_{2} \mathrm{O}_{3}$ はその蒸気压がかなり高いことから， 揮発除去されることが十分に考えられる。一方 $\mathrm{Sb}_{2} \mathrm{O}_{3}$ は気 相では $\mathrm{Sb}_{4} \mathrm{O}_{6}$ となるのでフンチモンの酸化揮発は式(14)，

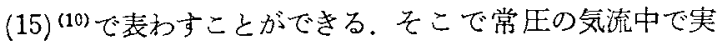

$$
\begin{array}{r}
\frac{4}{3} \mathrm{Sb}(\mathrm{I})+\mathrm{O}_{2}(\mathrm{~g})=\frac{1}{3} \mathrm{Sb}_{4} \mathrm{O}_{6}(\mathrm{~g}) \\
\Delta \mathrm{G}_{\mathrm{T}}^{\mathrm{o}}=-154420+63.64 \mathrm{~T}
\end{array}
$$

際渾発除去が進む一心限度として $p_{\mathrm{Sb}_{4} \mathrm{O}_{6}}=10^{-3}(\mathrm{~atm})$ と仮定し ${ }^{(11)}, p_{\mathrm{O}_{2}}=0.21$ とすれば, $1000^{\circ} \mathrm{C}$ において $a_{\mathrm{Sb}}=$ $2.02 \times 10^{-10}$ ，すなわち $2.96 \times 10^{-6} \mathrm{wt} \% \mathrm{Sb}$ となり銀中から さらにアンチモンを除去することが可能となる。

一方アンチモンと金についてす同様の計算をおこなって みると， $1000^{\circ} \mathrm{C}$ で $97,1200^{\circ} \mathrm{C} て ゙ 98 \mathrm{wt} \%$ Au以上の組成

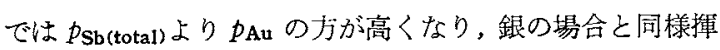
発除去は困難である。しかし酸化除去を考えた場合には， 銀の場合よりるさらに容易にフンチモンを除去することが できるこは明らかである。

\section{V. 結論}

溶融 $\mathrm{Sb}-\mathrm{Ag}$ 和よび Sb-Au 2 元系合金について, 流動法 を用いて $1000,1100,1200^{\circ} \mathrm{C}$ の温度で，ほぼ全組成範囲に
わたって蒸気圧を測定し，活量を初めとする熱力学的諸量 を求めて次のような結果を得た。

(1) Sb-Ag，Sb-Auいずれの系に拈いても各成分の活量 はRaoult 則より負に偏倚するが，フンチモンの活量はフ ソチモン側でわずが正に偏倚する。

(2) アンチモンの活量は $\mathrm{Ag}$ ，Auどちらの系においても 低アンチモン側のある組成で活量の温度化存性が逆転し， これよりアンチモン希薄側で恃正常であるが，反対にアン チモンに富を大部分の絽成で温度の上昇とともに Raoult 則からの偏倚が大きくなるといら特異な挙動を示す。

(3) 活量値より算出した部分混合熱 $\Delta \bar{H}_{\mathrm{Sb}}$ 洼どちらの系 においてもアンチモンの減少とともに正から負へと变化 し，このよらな傾向は起電力法によっても認められている ことかららアンチモン系融体に共通の現象と推察される。

本研究をまとめる比当り有益な御助言を頂いた東北大学 選鉱製錬研究所矢沢 樹教授に厚く感謝する。蓑た直接実 駼济力された位藤昭一工学士，清水 正工学修士に感謝 する。

\section{文献}

(1) T.Nozaki, M.Shimoji and K.Niwa : Berichte der Bunsengesellschaft, 70, (1966), 207.

(2) K.Okajima and H.Sakao : Trans JIM, 15(1974), 51.

（3）植村 治：東北大学博士論文(1970).

（4）象田和夫，阿座上竹四，龟田渶雄：金属学会誌，38 $(1974), 434$.

(5) J.L.Margrave: The Characterization of HighTemperature Vapors, John Wiley \& Sons, (1967), 91.

(6) R.Hultgren, P. D. Desai, D. T. Hawkins, M. Gleiser, K.K. Kelley and D.D.Wagman : Selected Values of the Thermodynamic Properties of the Elements, American Society for Metals, (1973), 443.

(7) M.Hansen and K.Anderko : Constitution of Binary Alloys, McGraw-Hill, (1958), 48, 230.

(8) O.Kubaschewski, E.L1.Evans and C.B.Alcock : Metallurgical Thermochemistry, 4 th edition, Pergamon Press, (1967), 65.

（9）阿座上竹四，矢沢 彬：日本鉱業会誌，83(1967), 666 .

（10）刍田满雄，矢沢 檘：治金物理化学々製錬基礎論 (吾妻編)，朝倉書店, (1960), 76 .

(11) H.H.Kellogg : Trans.Met.Soc.AIME, 236(1966), 602 . 